\title{
RAPID PCR-BASED DETECTION OPTIMIZATION OF PORCINE DNA IN GELATIN CAPSULE SHELL
}

\author{
AMALIA SITTI KHAYYIRA, VIKTORIA MARDHIKA ESTEPANE, AMARILA MALIK* \\ Division of Pharmaceutical Microbiology and Biotechnology, Faculty of Pharmacy, Universitas Indonesia, UI Depok Campus, Depok, \\ Indonesia 16424 \\ Email: amarilamalik@ui.ac.id \\ Received: 29 Aug 2018, Revised and Accepted: 21 Sep 2018
}

\begin{abstract}
Objective: This study was conducted to optimize the genomic deoxyribonucleic acid (DNA) based molecular detection of gelatin derived from porcine by performing polymerase chain reaction-restriction fragment length polymorphism (PCR-RFLP) and duplex PCR method employing cyt B gene.

Methods: Optimization was carried out for DNA extraction, PCR conditions, and the sensitivity of the PCR-RFLP method. Due to the very low DNA trace in gelatin after the various manufacturing process, the extraction was optimized to obtain sufficient DNA which was visible on the agarose gel. PCR-RFLP was carried out using universal primers and BsaJI restriction enzyme, and duplex PCR was carried out using two sets of porcine-specific primers. Porcine and bovine DNA were mixed in various concentration to confirm sensitivity of both methods, i.e. $100 \%, 50 \%, 10 \%, 1 \%$, $0.5 \%$,
\end{abstract} $0.1 \%, 0.05 \%$, and $0.01 \%$

Results: Both methods, PCR-RFLP, and Duplex PCR, were able to detect as low as 0.01\% porcine DNA, indicated by the presence of porcine DNA amplicon bands (131 bp and 228 bp for PCR-RFLP, $212 \mathrm{bp}$ and $398 \mathrm{bp}$ for duplex PCR). Although DNA bands presented in low intensity, identification of porcine and bovine species and estimation of DNA quantities were possible.

Conclusion: Both conventional PCR methods, i.e. PCR-RFLP and Duplex PCR, were sensitive, specific, and suitable as a rapid initial detection method for molecular detection of porcine in gelatin capsule shells.

Keywords: PCR-Based, Optimization of porcine DNA

(C) 2018 The Authors. Published by Innovare Academic Sciences Pvt Ltd. This is an open-access article under the CC BY license (http://creativecommons.org/licenses/by/4.0/) DOI: http://dx.doi.org/10.22159/ijap.2018v10i6.29346

\section{INTRODUCTION}

Gelatin is a group of polypeptides produced from collagen hydrolysis, which is extracted from the skin, bones, and connective tissue of animals [1]. There are many sources of gelatin, namely chicken, pork, beef, fish, and poultry. In 2009, gelatin was mostly produced from pig skins (46\%), cow hides (29.4\%), cow bones (23.1\%), and other sources (1.5\%) [2].

In the provisions of Islam, consuming non-halal products, including derivative products from porcine, is a prohibition. This made gelatin products which originally from porcine, are included in materials prohibited for consumption by adherents of this religion. A country with large Muslim population, e. g. Indonesia of $87.18 \%$ [3], has been designing regulations on halal product assurance, i.e. Law no. 33 y 2014.

A sensitive and reproducible method for detecting the presence of porcine-derived gelatin in pharmaceutical products has been intensively reported, which based on protein as well as deoxyribonucleic acid (DNA). The analytical method based on physicochemical characteristics and protein analysis such as chemical precipitation, fourier-transform infrared (FTIR) [4], electrophoretic analysis [5], high performance liquid chromatography (HPLC) [6], mass spectroscopy [7], as well as enzyme-linked immunosorbent assay (ELISA) [8] have been developed to distinguish different sources of gelatin. However, these methods are proved unsuitable due to protein degradation by extreme temperature and $\mathrm{pH}$ during production and the similarities in structure and physicochemical properties of gelatin derived from different sources [9]. Therefore, a nucleic acid-based analysis has been developed as an alternative method, i.e. polymerase chain reaction (PCR) method [1]. Several PCR-based methods such as PCRsouthern hybridization $[1,10]$, polymerase chain reactionrestriction fragment length polymorphism (PCR-RFLP) [11, 12], real-time PCR [13], nested-PCR [14], and multiplex PCR [13] have widely established and proved that PCR-based analysis is sensitive and specific in identifying several species in low amount of DNA.
Here we reported the optimization of DNA extraction as well as PCR detection of the DNA by performing two well-known methods, i.e. PCR-RFLP and duplex PCR, for porcine identification in gelatin capsule shells. The traces amount of DNA contained in the gelatin of the capsule shell is very low [13]. Therefore, optimization of DNA extraction methods to obtain an adequate amount of DNA for the template in PCR is required. In addition, the sensitivity of PCR methods assessment was also carried out by performing a mixture of porcine DNA and bovine DNA.

\section{MATERIALS AND METHODS}

\section{Materials}

Male pig genomic DNA (Cat no. GP-160M, Zyagen, USA) and male bovine genomic DNA (Cat no. GB-110M, Zyagen, USA) were used as the DNA references in PCR-RFLP and duplex PCR. A total of three pharmaceutical hard gelatin capsules (Capsule A, Capsule J, and Capsule S) from different sources were assessed. Capsule A was an orange-white hard capsule originated from Indonesia with an unknown source of gelatin. Capsule J was a translucent hard capsule containing porcine gelatin originated from Japan. Capsule $\mathrm{S}$ was a translucent capsule obtained from a Spain-produced supplement product containing an unknown source of gelatin.

\section{Optimization of DNA extraction}

Three types of capsule shell from different brands and sources were minced using sterile scissors aseptically. The small minced of capsule shells were processed for DNA extraction by using a columnbased DNeasy ${ }^{\circledR}$ Mericon Food Kit (Qiagen, Germany) as described by the manufacturer. Initially, $1 \mathrm{ml}$ of lysis buffer and $2.5 \mu \mathrm{l}$ of proteinase-K solution were added to approximately $200 \mathrm{mg}$ of the minced capsule shell and then were incubated for $30 \mathrm{~min}$ at $60^{\circ} \mathrm{C}$ in a $1000 \mathrm{rpm}$ shaking incubator. The solution was cooled to room temperature $\left(15-25^{\circ} \mathrm{C}\right)$ and was centrifuged for $5 \mathrm{~min}$ at $2,500 \mathrm{x} \mathrm{g}$. After centrifugation, $700 \mu \mathrm{l}$ of clear supernatant was transferred to a 
microcentrifuge tube containing $500 \mu \mathrm{l}$ of chloroform. The mixture was homogenized with a vortex mixer for $15 \mathrm{~s}$ and centrifuged at $14,000 \mathrm{x} g$ for $15 \mathrm{~min}$. Subsequently, $250 \mu \mathrm{l}$ of the upper aqueous phase was transferred to a sterile $2 \mathrm{ml}$ microcentrifuge tube containing $1 \mathrm{ml}$ of the binding buffer and homogenized with vortex mixer thoroughly. Then, $600 \mu \mathrm{l}$ of the mixture was transferred into a spin column, followed by centrifugation at $17,900 \mathrm{xg}$ for $1 \mathrm{~min}$. The flow-through was discarded. This step was repeated with the remaining sample. Afterward, $500 \mu \mathrm{l}$ of the wash buffer was added to the spin column, centrifuged at $17,900 \mathrm{x}$ g for $1 \mathrm{~min}$, and the flowthrough was discarded. The spin column was centrifuged again at $17,900 \mathrm{xg}$ for $1 \mathrm{~min}$ to dry the membrane, and the flow-through was discarded. Finally, the spin column was transferred to a sterile 1.5 $\mathrm{ml}$ microcentrifuge tube, $30 \mu \mathrm{l}$ of the elution buffer was added onto the membrane, incubated for $1 \mathrm{~min}$ at room temperature, and then centrifuged at $17,900 \times \mathrm{g}$ for $1 \mathrm{~min}$. The extracted DNA was visualized in $1 \%$ agarose gel in $1 \mathrm{X}$ Tris-acetate-EDTA (TAE) buffer stained with ethidium bromide, and a $1 \mathrm{kbp}$ DNA ladder (New England Biolabs, USA) was used as a size reference.

Due to the high degradation rate of the gelatin manufacturing process, the DNA extraction process was modified to maximize the recovery of DNA fragments until the DNA could be observed on an agarose gel. Several steps of the DNA extraction protocol, such as sample preparation, proteinase $\mathrm{K}$ lysis incubation, centrifugation time, and volume of elution buffer added were adjusted. Subsequently, the DNA was quantified using NanoDrop ${ }^{\mathrm{TM}} 1000$ Spectrophotometer (Thermo Scientific, USA) to determine the concentration and purity. The extracted DNA concentration was determined by UV absorbance at $260 \mathrm{~nm}$, and its purity was determined by the ratio of absorbance at 260 and $280 \mathrm{~nm}$.

\section{Primer characterization analysis}

One pair of universal primer and two pairs of porcine-specific primers were selected from the literature review, as listed in table 1 . Prior using the oligonucleotide primer data, we confirmed the sequences by aligning to National Center for Biotechnology Information (NCBI) database by performing Basic Local Alignment Search Tool (BLAST ${ }^{\circledR}$ ) [https://blast. ncbi. nlm. nih. gov/Blast. cgi]. The characteristics of primers, such as total bases, GC content, melting temperature (Tm), hairpin and dimer formation were also checked by using Oligo-Analyzer 3.1 [https://sg. idtdna. com/calc/analyzer]. Annealing sites of both pairs of primer to porcine genomic DNA were checked with Sequence Manipulation Suite (SMS): [http://www. bioinformatics. org/sms2/primer_map. $\mathrm{html}]$. Virtual electrophoresis pattern was built with MFEprimer [http://biocompute. bmi. ac. cn/CZlab/MFEprimer-2.0/]. After all set, the oligonucleotides were ordered to PT Genetika Science Indonesia, in affiliation with IDTDNA.

Table 1: Characteristics of an oligonucleotide primer used in this study

\begin{tabular}{|c|c|c|c|c|c|c|}
\hline Primer & $\begin{array}{l}\text { Length } \\
\text { bp }\end{array}$ & $\begin{array}{l}\text { Tm } \\
{ }^{\circ} \mathrm{C}\end{array}$ & $\%$ GC & $\Delta$ G Dimer (kcal. mol-1) & $\Delta$ G Hairpin(kcal. mol-1) & References \\
\hline F: TAAATCGCCCCTTCCTGGCAATA & \multirow[t]{2}{*}{212} & 56.3 & 47.8 & -3.14 & -0.5 and 0.48 & \multirow[t]{2}{*}{ Lahiff et al. (2001) } \\
\hline R: AAAATGGAGGCAAGAAATTTTTCG & & 51.8 & 33.3 & -5.46 and -5.36 & 0.46 and 0.56 & \\
\hline F: GACCTCCСАGСССССТСАААСАТC & \multirow[t]{3}{*}{398} & 66.6 & 50 & -2.17 and- 1.37 & -18.54 and -5 & \multirow[t]{3}{*}{ Srivastava et al. (2015) } \\
\hline TCATCATGATGAAA & & 56.2 & 40.7 & -3.61 and-3.14 & 1.23 and 1.46 & \\
\hline $\begin{array}{l}\text { R: GCTGATAGTAGATTTGTGATGAC } \\
\text { CGTA }\end{array}$ & & & & & & \\
\hline F: CCATCCAACATCTCAGCATGATG & \multirow[t]{3}{*}{359} & 57.5 & 42.3 & -5.38 and -5 & -2.17 & \multirow[t]{3}{*}{ Kocher et al. (1989) } \\
\hline AAA & & 58.5 & 46.2 & -3.91 & -0.25 and -0.02 & \\
\hline $\begin{array}{l}\text { R: GCCCCTCAGAATGATATTTGTCC } \\
\text { TCA }\end{array}$ & & & & & & \\
\hline
\end{tabular}

\section{Polymerase chain reaction}

DNA reference was processed for PCR-RFLP. Optimization of PCR condition was done by selecting the suitable and best PCR kit (especially its DNA polymerase enzyme) which gave satisfying results, i.e. intensive amplicon bands without nonspecific band appeared. Porcine and bovine DNA references were used as DNA template. Two PCR kits were used in this experiment, i.e. KAPA $\mathrm{HiFi}^{\mathrm{TM}}$ (Biosystems, USA) and KOD-Plus-Neo (Toyobo, Japan).

PCR using KAPA HiFi ${ }^{\mathrm{TM}}$ kit was performed in a final volume of $50 \mu \mathrm{l}$ containing approximately $200 \mathrm{ng}$ of DNA reference, $5 \mu \mathrm{l}$ of $10 \mathrm{X}$ buffer with $\mathrm{MgCl}_{2}, 1.5 \mu \mathrm{l}$ of each dNTPs, $1.5 \mu \mathrm{l}$ of each primer, and 0.7 $\mu \mathrm{l}$ of $\mathrm{KAPA} \mathrm{HiFi}^{\mathrm{TM}}$ polymerase. The cycling conditions included initial denaturation at $95{ }^{\circ} \mathrm{C}$ for $3 \mathrm{~min}$; followed by 35 cycles of denaturation at $98{ }^{\circ} \mathrm{C}$ for $20 \mathrm{~s}$, annealing at $55^{\circ} \mathrm{C}$ for $30 \mathrm{~s}$, and elongation at $72{ }^{\circ} \mathrm{C}$ for $30 \mathrm{~s}$; and post-elongation at $72{ }^{\circ} \mathrm{C}$ for $1 \mathrm{~min}$.

PCR using KOD-Plus-Neo kit was performed in a final volume of 50 $\mu \mathrm{l}$ containing $\sim 200 \mathrm{ng}$ DNA reference, $5 \mu \mathrm{l}$ of $10 \mathrm{X}$ buffer, $3 \mu \mathrm{l}$ of $\mathrm{MgSO}_{4}, 5 \mu \mathrm{l}$ of each dNTPs, $1 \mu \mathrm{l}$ of each primer, and $0.7 \mu \mathrm{l}$ of KODPlus-Neo enzyme in a final volume of $50 \mu$ l. The cycling conditions were initial denaturation at $94^{\circ} \mathrm{C}$ for 2 min; followed by 35 cycles of denaturation at $98{ }^{\circ} \mathrm{C}$ for $10 \mathrm{~s}$, annealing at $55^{\circ} \mathrm{C}$ for $30 \mathrm{~s}$, and elongation at $68^{\circ} \mathrm{C}$ for $30 \mathrm{~s}$; and post-elongation at $68^{\circ} \mathrm{C}$ for $2 \mathrm{~min}$.

PCR products were analyzed in $2 \%$ agarose gel in $1 \mathrm{X}$ Tris-borateEDTA (TBE) buffer stained with ethidium bromide, and a $100 \mathrm{bp}$ DNA ladder (Thermo Scientific, USA) was used as a size reference. Amplifications were carried out for both bovine and porcine DNA references, as well as DNA extracted from gelatin capsule shells.

PCR-RFLP was performed as described previously by (Malik et al. 2016). Amplicon DNA was subjected to digestion by using Bsa JI restriction enzyme (New England Biolabs, USA). Digestion was performed in a total volume of $30 \mu \mathrm{l}$ containing $15 \mu \mathrm{l}$ of pure DNA, 1 $\mu \mathrm{l}$ of $B s a \mathrm{I} I$ restriction enzyme, $3 \mu \mathrm{l}$ of $1 \mathrm{X} \mathrm{CutSmart}^{\mathrm{TM}}$ buffer, and $11 \mu \mathrm{l}$ of purified water. The mixture was then incubated for $2.5 \mathrm{~h}$, followed by enzyme inactivation at $80{ }^{\circ} \mathrm{C}$ for $20 \mathrm{~min}$. The digested DNA was analyzed in $2 \%$ agarose gel in $1 \mathrm{X}$ TBE buffer stained with ethidium bromide, and a 100 bp DNA ladder (Thermo Scientific, USA) was used as a size reference.

Duplex PCR was carried out using two porcine-specific primers [16, 17] simultaneously. Annealing temperature was optimized to obtain the most effective amplification result. The variation of annealing temperatures assessed by duplex PCR method was $55^{\circ} \mathrm{C}, 56^{\circ} \mathrm{C}$, and $57^{\circ} \mathrm{C}$. The amplicon DNA obtained was observed on $2 \%$ agarose gel in $1 \mathrm{X}$ TBE buffer stained with ethidium bromide, and a 100 bp DNA ladder (Thermo Scientific, USA) was used as a size reference.

\section{Sensitivity test of PCR-RFLP and duplex PCR}

The sensitivity of the PCR-RFLP and duplex PCR method was performed by assessing the detection sensitivity of porcine genomic DNA reference in mixture with bovine genomic DNA reference with several concentration levels: $100 \% ; 50 \% ; 10 \% ; 1 \% ; 0.5 \% ; 0.1 \%$; $0.05 \%$; and $0.01 \%$. For the PCR-RFLP method, these various concentrations of porcine-bovine DNA mixtures were subjected to amplification, purification, and digestion. The results from two methods were observed on agarose gel electrophoresis and confirmed by comparing the intensity of the bands using my Image Analysis $^{\mathrm{TM}}$ (Thermo Scientific) software. The data obtained was subsequently processed to analyze the linearity of various concentrations of porcine DNA in mixtures with bovine DNA. For duplex-PCR, the linearity was also analyzed by using NanoDrop ${ }^{\mathrm{TM}}$ Spectrophotometer. Furthermore, the sensitivity of the method was 
determined by the detection of the lowest porcine genomic DNA concentration in the mixture.

\section{RESULTS AND DISCUSSION}

Literatures review and in silico analysis were performed to determine the primers used in this study: universal primer pair for PCR-RFLP [15] and two sets of primer pairs for duplex PCR [16, 17]. Analysis of primer characteristics was summarized in table 1 . The $212 \mathrm{bp}$ primer amplifies the porcine mitochondrial DNA in the site of DNA sequences encoding lysine tRNA and subunit of ATP synthase F0 8. ATP synthase plays a role in the production of ATP from ADP in the presence of a proton gradient across the membrane facilitated by electron transport in the respiratory chain [18]. The $359 \mathrm{bp}$ and $398 \mathrm{bp}$ primer amplifies the porcine mitochondrial DNA in the site of the DNA sequences encoding cytochrome $b$ (cyt $b$ ). The cyt $b$ gene is often used in the phylogenic tracing of a species of the same genus or family, and widely used in the differentiation of vertebrate species because they have interspecies variations $[19$, 20].

\section{Optimization of DNA extraction}

The optimization of DNA extraction from the capsule shell was summarized in table 2 . The extraction was optimized from the method as described by (Nikzad et al. 2017) [13] but with several replication and modification in order to obtain DNA band profile which able to be visualized in each extraction result and DNA concentration measurement. From four modifications, we were able to obtain optimum DNA amount from extraction result which gave the most acceptable result using modifications in E5, i.e. four sample replicates, each tubes containing $300 \mathrm{mg}$ minced capsule shells, with initial incubation using 4 $\mu \mathrm{l}$ proteinase-K for $180 \mathrm{~min}$, followed by $500 \mu \mathrm{l}$ wash buffer, and final elution using $2 \times 30 \mu$ elution buffer with incubation time of $5 \mathrm{~min}$.

Table 2: Modification applied for optimization of DNA extraction

\begin{tabular}{|c|c|c|c|c|c|c|}
\hline Parameters & Kit & E1 & E2 & E3 & E4 & E5 \\
\hline Capsule shells (mg) & 200 & 300 & 300 & 300 & 300 & 300 \\
\hline Replicates (tube) & - & 3 & 3 & 3 & 4 & 4 \\
\hline Proteinase- $\mathrm{K}(\mu \mathrm{l})$ & 2.5 & 4 & 25 & 25 & 4 & 4 \\
\hline Wash buffer $(\mu \mathrm{l})$ & 500 & 500 & 300 & 300 & 300 & 500 \\
\hline Elution buffer $(\mu l)$ & 150 & 30 & 30 & 30 & 30 & $30(x 2)$ \\
\hline Incubation time after minced DNA capsule shells were mixed with proteinase-K and lysis buffer (min) & 30 & 180 & 180 & 180 & 180 & 180 \\
\hline Incubation time after elution buffer was added into the spin column containing DNA (min) & 1 & 1 & 5 & 5 & 5 & 5 \\
\hline Centrifugation time ${ }^{a}(\mathrm{~min})$ & 1 & 1 & 2 & 2 & 2 & 2 \\
\hline
\end{tabular}

${ }^{a}$ Centrifugation time in all process involved after DNA was transferred into the spin column

Approximately $300 \mathrm{mg}$ of samples were used in four replications in order to increase the yield of extracted DNA. These four replicate samples were then transferred to the same spin column, thus the DNA amount accumulated in the column would increase the DNA recovery. Gelatin is known to be obtained from collagen hydrolysis, which undergoes harsh condition such as denaturation by heating, acid treatment, washing, and drying. Therefore, it is assumed that the DNA could be degraded. This high degradation rate of gelatin manufacturing steps followed by a various process of turning the gelatin to capsule could decrease the amount of DNA.

Gelatin capsule shells were difficult to dissolve in lysis buffer even though they were mixed intensively by vortex prior to dissolve. Therefore, heating in a water bath at $60^{\circ} \mathrm{C}$ for $60 \mathrm{~min}$ and mixing by vortex every $10 \mathrm{~min}$ were required to dissolve completely before the samples subjected to incubation. The amount of proteinase-K, which was added to facilitate DNA separation from protein and cell contaminant, was increased. Due to the insignificant difference between the use of $4 \mu \mathrm{l}$ and $25 \mu \mathrm{l}$ of proteinase-K, we concluded that $4 \mu \mathrm{l}$ of proteinase-K was effective enough for DNA extraction. The incubation time after addition of proteinase- $\mathrm{K}$, as stated by the manufacturer, was increased from $30 \mathrm{~min}$ to $180 \mathrm{~min}(3 \mathrm{~h})$ in order to maximize cell lysis and released of DNA. The centrifugation time in all process involved after transferring into a spin column was increased to $2 \mathrm{~min}$ for maximum binding, washing, and elution of DNA. The elution buffer was decreased to $30 \mu \mathrm{l}$ but repeated once more, in order to obtained more concentrated DNA in $60 \mu \mathrm{l}$ volume but sufficient for further steps.

Visualization of DNA from extraction on agarose gel showed smearing bands which confirmed that the DNAs is in hardly degraded condition [21]; while if there is no band appeared, it was possibly due to the extremely low amount of DNA extracted.

To confirm the concentration of DNA obtained from the extraction, the concentration and purity of DNA samples were measured using NanoDrop ${ }^{\mathrm{TM}}$ ND-100 spectrophotometer. The capsule S, which had the highest concentration $(56.30 \mathrm{ng} / \mu \mathrm{l})$, showed more intensive band; while capsule A at a concentration of $15.04 \mathrm{ng} / \mu \mathrm{l}$ showed a less intensive band; and the capsule $\mathrm{J}$ at a very low concentration $(4.03 \mathrm{ng} / \mu \mathrm{l})$ did not show any band. This difference was possibly due to the way the gelatin generated of each capsule shell, resulting in the various amount of DNA trace. However, it was assumed that capsule J can be still extracted successfully even with low concentration. The purity of DNA, measured in the ratio of A260/280 was acceptable. The ideal range of A260/280 is $\sim 1.8$ for DNA and $\sim 2.0$ for RNA [22]. Therefore, it was concluded that the optimized extraction method produced sufficient DNA yield with acceptable quality.

\section{Optimization of PCR-RFLP}

PCR-RFLP Optimization was done by selecting the best DNA polymerase enzyme. Both KAPA HiFi ${ }^{\mathrm{TM}}$ (High Fidelity) and KODPlus-Neo PCR Kit offer better accuracy and proofreading ability than Taq polymerase as mentioned by the manufacturer. DNA polymerase from KAPA $\mathrm{HiFi}^{\mathrm{TM}}$ Kit is B-family DNA polymerase that has been engineered to have a better affinity for DNA and a significant increase in PCR yield with higher reaction speed and sensitivity than other wild-type B-family DNA polymerase. The DNA polymerase of the KOD-Plus-Neo kit is produced by Thermococcus kodakaraensis. This type of polymerase DNA has a good proofreading ability that can produce amplicons with excellent accuracy. In addition, this enzyme also shows better elongation and efficiency capabilities due to the 'elongation enhancer' feature [23].

As shown in fig. 1-A, the PCR amplification produced amplicon bands of approximately $360 \mathrm{bp}$ length for both porcine and bovine. This result is consistent with the result reported for porcine and bovine amplifications using universal cyt $b$ primer pairs [12].

Both bovine and porcine DNA amplification with $\mathrm{KAPA} \mathrm{HiFi}^{\mathrm{TM}}$ exhibited similar result, i.e. nonspecific band around $200 \mathrm{bp}$, and bands below $100 \mathrm{bp}$ (fig. $1 \mathrm{~A}$ ), the latter presumed as the presence of primer dimers. These indicated that KAPA $\mathrm{HiFi}^{\mathrm{TM}} \mathrm{i}$ did not specifically amplify the right sequences. While both bovine and porcine DNA amplification with KOD-Plus-Neo enzyme showed clear and sharp bands without any nonspecific bands.

This result clearly showed that KOD-Plus-Neo enzyme performed better amplification than KAPA $\mathrm{HiFi}^{\mathrm{TM}}$ enzyme and presented acceptable result, i.e. specific, sharp, and intense bands; therefore, KOD-Plus-Neo was selected as the most suitable enzyme for the next amplification reactions. 
(A)

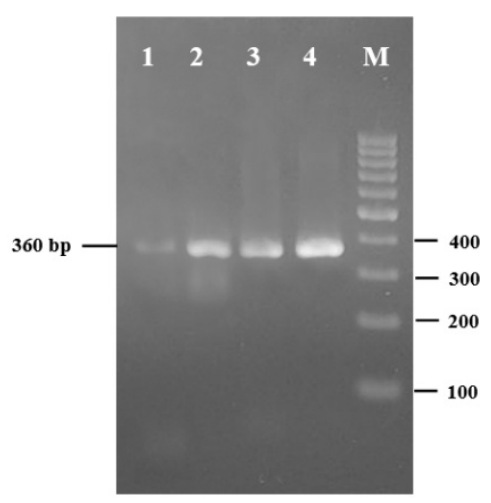

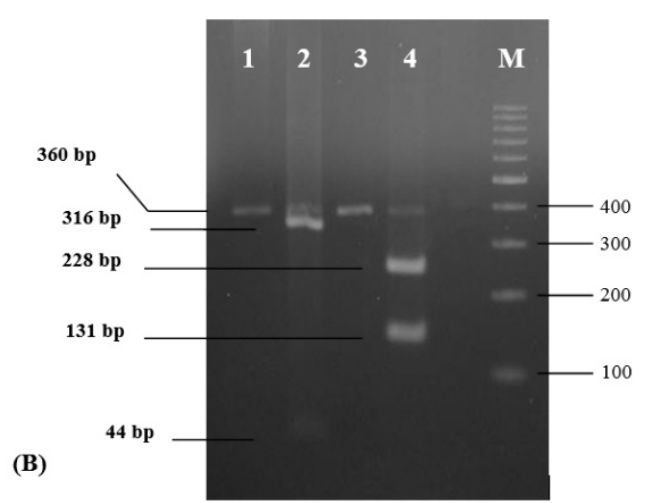

Fig. 1: Agarose gel electrophoresis of: (A) PCR product amplification by KAPA HiFi' ${ }^{\mathrm{TM}}$ and KOD-Plus-Neo from porcine and bovine DNA reference. KAPA HiFi'T: lane 1, bovine; lane 2, porcine. KOD-Plus-Neo: lane 3, bovine; lane 4, porcine; (B) digested gelatin DNA reference. Lane 1, undigested bovine DNA; lane 2, digested bovine DNA; lane 3, undigested porcine DNA; lane 4, digested porcine DNA. Lane M, 100 bp DNA ladder

Annealing temperature, which plays an important role in the successful amplification, was also treated for optimization. In this study, the variation of annealing temperatures assessed for duplex PCR method were $55^{\circ} \mathrm{C}, 56^{\circ} \mathrm{C}$, and $57^{\circ} \mathrm{C}$. The optimum annealing temperature is indicated by the apparent of both the desired amplicon bands and the absence of nonspecific bands in PCR electrophoresis.

Based on in silico analysis and reports by Aida et al. (2005), Malik et al. (2016), and Murugaiah et al. (2009) [11, 12, 24] the appropriate restriction enzyme to discriminate cytochrome $b$ DNAs of porcine and bovine is BsaJI enzyme. Correct DNA fragments, i.e. $316 \mathrm{bp}+44$ bp for bovine, and $228 \mathrm{bp}+131 \mathrm{bp}$ for porcine, can be observed on agarose gel after digestion at $60^{\circ} \mathrm{C}$ for $2.5 \mathrm{~h}$ (fig. $1 \mathrm{~B}$ ).

\section{Optimization of duplex PCR}

To determine the most appropriate PCR kit to be used, experiments were performed by using reference DNAs of porcine and bovine and by using two PCR kits. As shown in fig. 2, the PCR duplex amplification using both PCR kits produced specific bands with the absence of an amplicon band on bovine DNA reference and the presence of an amplicon band on porcine DNA reference. However, the difference in PCR amplicon yields of both kits can be observed. The porcine bands ( $212 \mathrm{bp}$ and $398 \mathrm{bp}$ ) were seen in amplification result by KOD-Plus-Neo, but the intensity was very low and significantly different from the reference amplicon bands. While, there was a nonspecific band at lower than $100 \mathrm{bp}$ amplified by KAPA $\mathrm{HiFi}^{\mathrm{TM}}$, which was suspected as a primer-dimer [25]. It can be confirmed that the PCR kit to be used was KOD-Plus-Neo; it showed more efficient amplification thus no primer remained to form dimer.

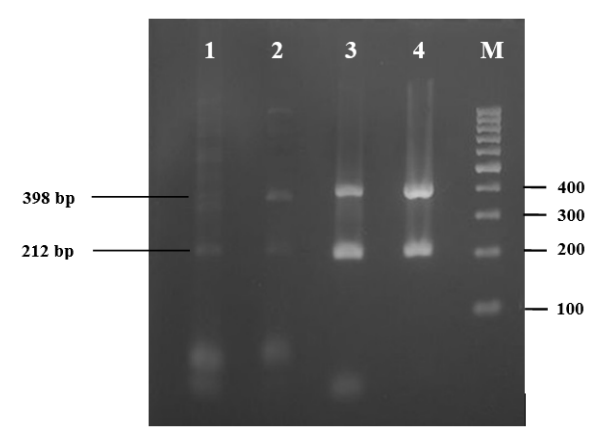

Fig. 2: Agarose gel of duplex PCR of porcine and bovine DNA references using KAPA HiFi ${ }^{\mathrm{TM}}$ PCR Kit and KOD-Plus-Neo PCR Kit. Lane 1, bovine (KAPA HiFi ${ }^{\mathrm{TM}}$ ); lane 2, bovine (KOD-PlusNeo); lane 3, porcine (KAPA HiFiTM); lane 4 (KOD-Plus-Neo); lane M. 100 bp DNA ladder

The result of annealing temperature optimization is shown in fig. 3 . The optimal annealing temperature was obtained at temperature $56^{\circ} \mathrm{C}$. This was concluded by the fact that employing bovine DNA reference amplification at $55{ }^{\circ} \mathrm{C}$ generated nonspecific band. Nonspecific bands may occur if the annealing temperature is too low, so the primer annealing becomes nonspecific to the site it should be. While in duplex PCR with annealing temperature at $57^{\circ} \mathrm{C}$, there was a nonspecific band of $212 \mathrm{bp}$ in bovine DNA reference amplification result. In addition, the $398 \mathrm{bp}$ amplicon band often does not appear or look very faint on the porcine DNA reference. This means that annealing temperature at $57^{\circ} \mathrm{C}$ was too high thus the $398 \mathrm{bp}$ primers were denatured before it could attach to the DNA template.
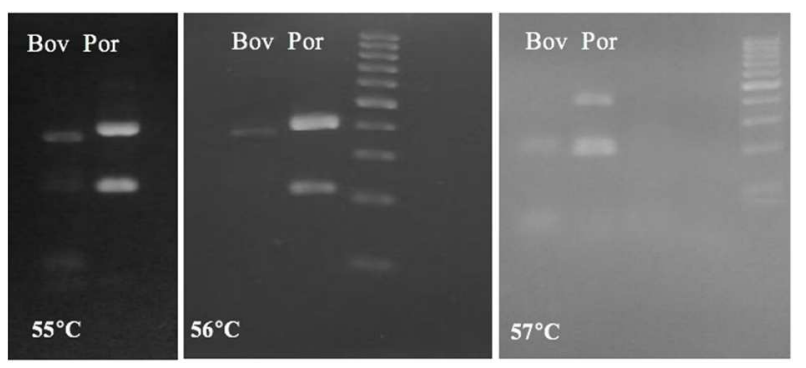

Fig. 3: Agarose gel of duplex PCR on various annealing temperatures, i.e. $55^{\circ} \mathrm{C}, 56^{\circ} \mathrm{C}$ and $57^{\circ} \mathrm{C}$. Bov, for bovine, Por for porcine

\section{PCR-RFLP and duplex PCR sensitivity}

PCR-RFLP and duplex PCR of mixture of DNA references were performed to determine the sensitivity of these methods in detecting porcine DNA content with low concentrations. Various concentrations were applied, i.e. $100 \%, 50 \%, 10 \%, 1 \%, 0.5 \%, 0.1 \%$, $0.05 \%$, and $0.01 \%$ of porcine DNA to bovine DNA. The results were shown in fig. 4 . It could be seen that both PCR-RFLP and duplex PCR were able to amplify the target sensitively and selectively.

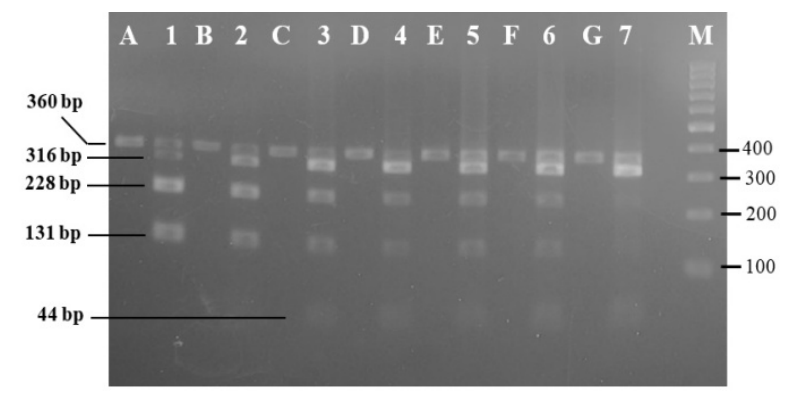

(A) 


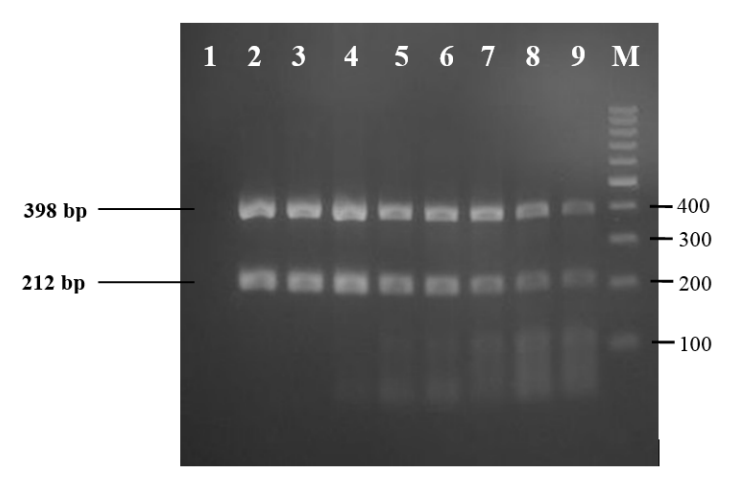

(B)

Fig. 4: Agarose gel of: (A) PCR-RFLP on mixture of porcine and bovine DNA reference in various concentrations. Lane $A-H$ amplicons/undigested porcine DNA of $50 \%, 10 \%, 1 \%, 0.5 \%$, $0.1 \%, 0.05 \%$, and $0.1 \%$, respectively. Lane $1-7$, digested porcine DNA of $50 \%, 10 \%, 1 \%, 0.5 \%, 0.1 \%, 0.05 \%$, and $0.01 \%$ respectively. (B) Duplex PCR on mixture of porcine and bovine DNA reference in various concentrations. Lane 1, bovine DNA reference $100 \%$; lane 2, porcine DNA reference $100 \%$. Lane 3-9, amplicons of porcine DNA reference with concentrations: $50 \%$, $10 \%, 1 \%, 0.5 \%, 0.1 \%, 0.05 \%$, and $0.01 \%$, respectively. Lane $M$, 100 bp DNA ladder (Thermo Scientific, USA)

By observing the agarose gel, it could be seen that the intensity of the bands generated was depend on the proportion of the species DNA in the mixture thus each concentration could be differed. The high intensity of DNA showed thicken band while faint band indicated the low intensity of DNA. The lower the DNA porcine concentration in the mixture, the porcine bands $(131 \mathrm{bp}$ and $228 \mathrm{bp}$ for PCR-RFLP, and $212 \mathrm{bp}$ and $398 \mathrm{bp}$ for duplex PCR) went fainter, while the bovine bands ( $44 \mathrm{bp}$ and $316 \mathrm{bp}$ for PCR-RFLP) became more intense and thicken. The lowest detectable concentration was indicated by the presence of porcine bands in $0.01 \%$ porcine: $228 \mathrm{bp}$ and $131 \mathrm{bp}$ for PCR-RFLP (fig. $4 \mathrm{~A}$ ), and $398 \mathrm{bp}$ and $212 \mathrm{bp}$ for duplex PCR (fig. 4 B). Hence, it appears that both PCR-RFLP and duplex PCR were able to detect porcine DNA in the mixture as little as $0.01 \%$.

The DNA bands of Duplex PCR were then quantified using myImageAnalysis ${ }^{\mathrm{TM}}$ (Thermo Scientific) (table 3).

Table 3: Interpretation of PCR-RFLP and duplex PCR bands by quantification

\begin{tabular}{|c|c|c|c|c|c|c|}
\hline \multirow[t]{2}{*}{$\%$ Por. } & \multirow[t]{2}{*}{ \% Bov } & \multicolumn{3}{|c|}{ PCR-RFLPa } & \multicolumn{2}{|c|}{ Duplex PCR $^{\text {b }}$} \\
\hline & & $131 \mathrm{bp}$ & 228 bp & 316 bp & 212bp & 398bp \\
\hline 100 & 0 & 34.73 & 39.88 & - & 14.61 & 14.30 \\
\hline 50 & 50 & 28.15 & 36.32 & 16.19 & 18.52 & 15.96 \\
\hline 10 & 90 & 17.20 & 23.99 & 19.46 & 22.26 & 17.22 \\
\hline 1 & 99 & 11.55 & 17.40 & 23.02 & 15.93 & 15.29 \\
\hline 0.5 & 99.5 & 10.71 & 15.42 & 26.37 & 15.94 & 17.22 \\
\hline 0.1 & 99.9 & 9.07 & 11.64 & 29.58 & 14.77 & 21.30 \\
\hline 0.05 & 99.95 & 5.05 & 10.78 & 31.87 & 10.66 & 13.15 \\
\hline 0.01 & 99.99 & 2.53 & 8.39 & 38.16 & 9.53 & 11.17 \\
\hline 0 & 100 & 一 & - & 23.63 & - & - \\
\hline
\end{tabular}

${ }^{\mathrm{a}}$ Measured with myImageAnalysis ${ }^{\mathrm{TM}}$ (ng), all bands of $44 \mathrm{bp}$ were undetectable, ${ }^{\mathrm{b}}$ Measured with myImageAnalysis ${ }^{\mathrm{TM}}$ software (ng), ${ }^{\mathrm{a}}$ Measured with myImageAnalysis ${ }^{\mathrm{TM}}(\mathrm{ng})$, all bands of $44 \mathrm{bp}$ were undetectable, ${ }^{\mathrm{b}}$ Measured with myImageAnalysis ${ }^{\mathrm{TM}}$ software (ng)

By conventional PCR, it is difficult to obtain quantitative results due to the plateau phase effect; it is a condition in a PCR reaction in which the exponential DNA accumulation of amplicons does not continue regardless of the DNA mold used, which generally occurs in some final cycles. There are several factors that can cause the plateau phase, such as the limited amount of dNTPs or primers used, the thermal inactivation and limited amount of DNA polymerase, reannealing the products of amplification, enzyme activity inhibition, as well as amplification product damage due to exonuclease activity [26]. Nevertheless, this result could be used as a preliminary estimation of the presence of porcine DNA, which is inexpensive, although the accuracy is less than $100 \%$.

Application of PCR method for the detection of porcine in gelatin capsule shells

The optimized duplex-PCR and PCR-RFLP method was applied to detect the porcine in the extracted gelatin capsule shell samples (fig.

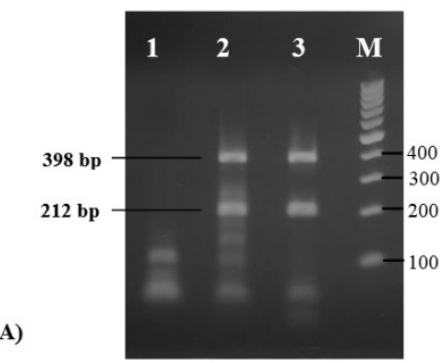

$5 \mathrm{~A}$ and $5 \mathrm{~B}$ ). There was no amplicon seen in PCR result of capsule A (fig. $5 \mathrm{~A}$, lane 1) and the capsule A was cleaved into smaller fragments of $316 \mathrm{bp}$ and $44 \mathrm{bp}$ (fig $5 \mathrm{~B}$, lane 1). This indicated that the capsule $\mathrm{A}$, which was obtained from a local pharmacy, proved to contain no porcine gelatin content. The amplicon bands of $212 \mathrm{bp}$ and 398 bp were clearly visible in capsule J, and S (fig. 5 A, lane 1 and 2 , respectively), and these capsules were also cut into fragments of $228 \mathrm{bp}$ and $131 \mathrm{bp}$ (fig. $5 \mathrm{~B}$, lane 1 and 2), thus it can be concluded that both capsule shells were confirmed to contain gelatin from porcine. The result for capsule $\mathrm{J}$ is in agreement with the manufacturer's label, which stated that it was made from pig.

However, considering the limitation of this study, further study with more capsule shell samples is required to obtain the reproducibility for the method; then this method can be compared economically with other nucleic acid-based analysis methods.
(B)

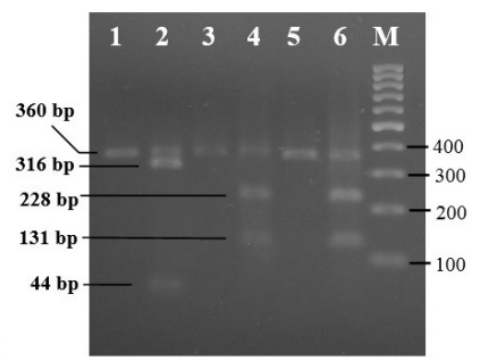

Fig. 5: Agarose gel of DNAs from gelatin capsule shell samples. (A) Duplex PCR result: lane 1, capsule A; lane 2, capsule J; lane 3, capsule S. (B) PCR-RFLP result: lane 1, 3, and 5 are undigested capsule $A, J$, S, respectively; lane 2, 4, and 6 are digested capsule A, J, S, respectively. Lane M, 100 bp DNA ladder (Thermo Scientific, USA) 


\section{CONCLUSION}

The DNA extraction method used in this study, DNeasy ${ }^{\circledR}$ Mericon Food Kit, which employing CTAB, had been optimized so that the DNA recovery was able to be visualized on the agarose gel. Both PCR-RFLP and duplex PCR were sensitive enough and appropriate in detecting porcine DNA in a mixture with a sensitivity of $0.01 \%$, and specific enough to identify three capsule shell samples from the market. Therefore, both methods are a suitable tool as an inexpensive early and routine detection method of porcine in gelatin capsule shells.

\section{ACKNOWLEDGMENT}

This work was partly funded by Research Grant PUPT 2016 and 2017 from Directorate for Higher Education, the Republic of Indonesia to A. M. Authors would like to thank Prof. R. Ismail, University of Malaya, for scientific English editing and discussions of this manuscript during his visit to Universitas Indonesia in 2017.

\section{AUTHORS CONTRIBUTIONS}

All the author have contributed equally

\section{CONFLICT OF INTERESTS}

The authors declare no conflict of interest. The funders had no role in the design of the study; in the collection, analyses, or interpretation of data; in the writing of the manuscript, and in the decision to publish the results.

\section{REFERENCES}

1. Sahilah AM, Fadly ML, Norrakiah AS, Aminah A, Wan Aida W, Ma'aruf AG, et al. Halal market surveillance of soft and hard gel capsules in pharmaceutical products using PCR and southernhybridization on the biochip analysis. Int Food Res J 2012;19:371-5.

2. Karim AA, Bhat R. Fish gelatin: properties, challenges, and prospects as an alternative to mammalian gelatins. Food Hydrocolloids 2009;23:563-76.

3. Badan Pusat Statistik [Internet]. Sensus Penduduk 2010Penduduk Menurut Kelompok Umur dan Agama yang Dianut. Available from: http://sp2010.bps.go.id/index.php/ site/tabel? searchtabel=Penduduk+Menurut+Kelompok+Umur+dan+Agama+ yang+Dianutandtid $=320$ andsearch-wilayah $=$ Indonesiaandwid $=0000000000$ andlang=id. [Last accessed on 29 Jan 2017].

4. Rohman A, Che Man Y, Hashim P, Ismail A. FTIR spectroscopy combined with chemometrics for analysis of lard adulteration in some vegetable oils Espectroscopia FTIR combinada con quimiometría para el análisis de adulteración con grasa de cerdo de aceites vegetales. CyTA J Food 2011;9:96-101.

5. Hermanto S, Fatimah W. Differentiation of bovine and porcine gelatin based on spectroscopic and electrophoretic analysis. J Food Pharm Sci 2013;1:68-73.

6. Nemati M, Oveisi M, Abdollahi H, Sabzevari O. Differentiation of bovine and porcine gelatins using principal component analysis. J Pharm Biomed Anal 2004;34:485-92.

7. Zhang G, Liu T, Wang Q, Chen L, Lei J, Luo J, et al. Mass spectrometric detection of marker peptides in tryptic digests of gelatin: a new method to differentiate between bovine and porcine gelatin. Food Hydrocolloids 2009;23:2001-7.

8. Venien A, Levieux D. Differentiation of bovine from porcine gelatines using polyclonal anti-peptide antibodies in indirect and competitive indirect ELISA. J Pharm Biomed Anal 2005;39:418-24.
9. Shabani H, Mehdizadeh M, Mousavi S, Dezfouli E, Solgi T, Khodaverdi M, et al. Halal authenticity of gelatin using speciesspecific PCR. Food Chem 2015;184:203-6.

10. Mutalib SA, Muin NM, Abdullah A, Hassan O, Aida W, Mustapha W, et al. Sensitivity of polymerase chain reaction (PCR)-southern hybridization and conventional PCR analysis for Halal authentication of gelatin capsules. LWT--Food Sci Technol 2015; 63:714-9.

11. Aida A, Che Man Y, Wong C, Raha A, Son R. Analysis of raw meats and fats of pigs using polymerase chain reaction for halal authentication. Meat Sci 2005;69:47-52.

12. Malik A, Sutantyo M, Hapsari I, Sinurat A, Purwati E, Jufri M, et al. Simultaneous identification and verification of gelatin type in capsule shells by electrophoresis and polymerase chain reaction. J Pharm Invest 2016;46:475-85.

13. Nikzad J, Shahhosseini S, Tabarzad M, Nafissi-Varcheh N, Torshabi M. Simultaneous detection of bovine and porcine DNA in pharmaceutical gelatin capsules by duplex PCR assay for halal authentication. Daru J Pharm Sci 2017;25:111.

14. Unajak S, Meesawat P, Anyamaneeratch K. Identification of species (meat and blood samples) using nested-PCR analysis of mitochondrial DNA. Afr J Biotechnol 2011;10:5670-6.

15. Kocher TD, Thomas WK, Meyer A, Edward SV, Paabo S, Villablanca FX. Dynamics of mitochondrial DNA evolution in animals: amplification and sequencing with conserved primers. Proceedings National Academy Sci USA 1898; 86:6196-200.

16. Lahiff S, Glennon M, O'Brien L, Lyng J, Smith T, Maher M, et al. Species-specific PCR for the identification of ovine, porcine and chicken species in meat and bone meal (MBM). Mol Cell Probes 2001;15:27-35.

17. Srivastava G, Rajput N, Jadav K, Shrivastav A, Joshi H. Single nucleotide markers of D-loop for identification of indian wild pig (sus scrofa cristatus). Vet World 2015;8:532-6.

18. Uniprot [Internet]. MT-ATP8-ATP synthase protein 8-Homo sapiens (Human)-MT-ATP8 gene and protein. Available from: https://www.uniprot.org/uniprot/P03928. [Last accessed on 16 Jul 2017].

19. Nuraini H, Primasari A, Andreas E, Sumantri C. The use of cytochrome $\mathrm{b}$ gene as a specific marker of the rat meat (Rattus Norvegicus) on meat and meat products. Media Peternakan 2012;35:15-20.

20. Gil Arriortua M, Salona Bordas M, Caine L, Pinheiro F, de Pancorbo M. Cytochrome B as A useful tool for the identification of blowflies of forensic interest (diptera, calliphoridae). Forensic Sci Int 2013;228:132-6.

21. Goodwin W, Linarce A, Hadi S. An introduction to forensic genetics. 1st ed. Chicester: John Wiley and Sons; 2007.

22. Desjardins P, Conklin D. Nanodrop microvolume quantitation of nucleic acids. J Visualized Exp 2010;45:2565.

23. Toyobo [Internet]. KOD-plus-neo: instruction manual KOD-plusneo 1109. Available from: http://www.toyobo-global.com/ seihin/xr/lifescience/products/pcr_016.html. [Last accessed on 28 Aug 2018].

24. Murugaiah C, Noor Z, Mastakim M, Bilung L, Selamat J, Radu S. Meat species identification and halal authentication analysis using mitochondrial DNA. Meat Sci 2009;83:57-61.

25. Poritz M, Ririe K. Getting things backwards to prevent primer dimers. J Mol Diagn 2014;16:159-62.

26. Kainz P. The PCR plateau phase-towards an understanding of its limitations. biochim biophys acta. Gene Struct Expression 2000;1494:23-7. 